冠功脤造影唡查におけるフィル夕効果について

115. Effect of Filters in Coronary Angiography

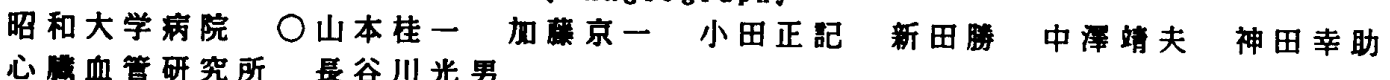

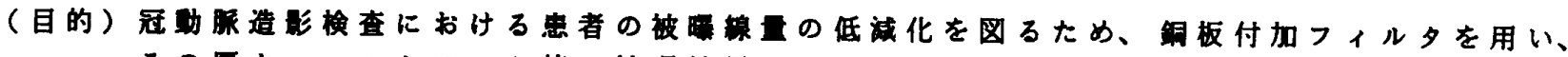
その厚さ、コントラスト值、被線鼻について検討した。

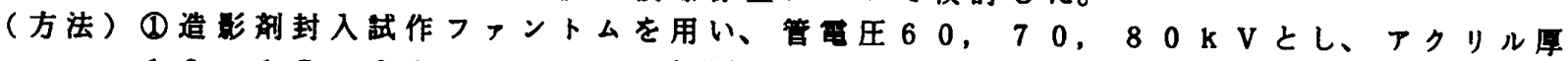

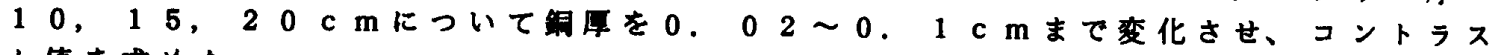

卜镇を求めた。

(2) T D を用い、局所被晒缐を测定した。

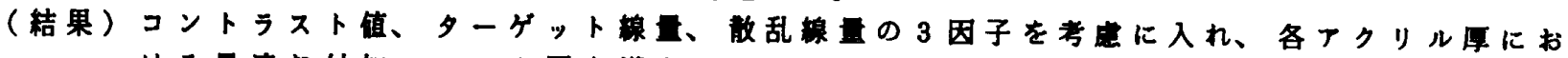
ける取な付加フィルタ看を亚をだした。

116.

$$
\text { Measurements of RVEF from single plane DSA }
$$

Measurements of RVEF from single plane DSA

帝京大学病院大筒 菒

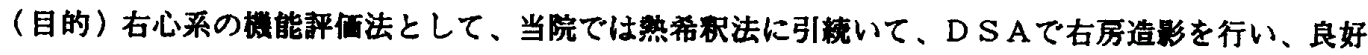
な結果が得られろいるので報告する。

（方法）右房へP I G T A I Lカテーテルを择入し、D S Aのコンティニィアスモードにて

$\mathrm{RAO} 30^{\circ}$ で秒间 30 フレーム䄪 10 秒间収羑する。

ROIをサブトラクション画像の1)右室拡張期 (2)右室収粕期 (8)右室近傍 の3っを取りそれ

ぞれ(1)-(3) (20の曲線からE DV，ESVを求めRVEFを計真する。

(結果) 手技が侖便で䠦床に即応用でき、また、右心系の評佰が可能なことがわかった。

\title{
117. Clinical Application of DCI in Pediatric Cardiology (PA index)
}

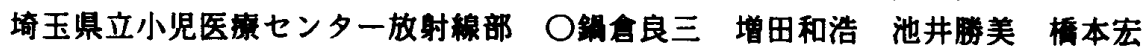

【目的】われわれは、第46回粘会学術大会において、小児心疾患におけるバイプレーンD C I の㤵床的検討を報告 した。今回は、D C I における識影画像データー収集後、本システムの画像解析の娜定を利用し、PAインテックス の計娜を行なってみた。肺血流娍少を示す小児の先天性心疾患は、手術道応の決定に际して肺峌䛲の発育度にP A ンデックスの計湘が用いられている。そこで、臨床的に使用できるか検討したので報告する。

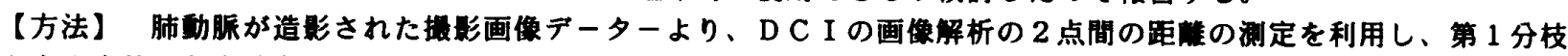
を出す直前の左右肺峌䛲の計测を行なって体表面棈で除した值を、実際のシネフィルムの测定したものと比交する。

【結果】PAインデックスの湘定は、通常模目䊏了後に掫影したシネフィルムの現像・絧集など処理を行なって から、計㑚しなければならず手間がかかる。しかし、D C I の画像解析を利用することによって、従来行なわれてい たPAインデックスの测定がスヒーティーに行なえた。また、模者間の再現性にも相闪が認められた。

D SA画像を用いた F u n c t i o n a l I m a g e の試み

118. Functional Image with Digital subtraction angiography

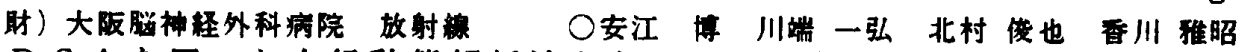

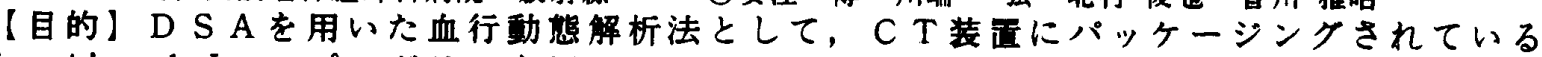
Functional Imageプログラムを用いて，D S A 画像によるFunctional Imageを作成するこ とを武みた。

【方法】D S A 画像は，通常ではC T 装酉で报うことができないので P C 9800 を用い て，MTファイル変换プロクラムにより，off line処理にてCT画像デー夕に㚆换しFunc tional Imageを作成した。また作成した画像の各種Transit Timeについて検村を行った。 【結果】避択的造影法や，動脈相のみを用いる等を行うことにより明䀳な画像を得ること ができる。評偭としては，部断上有用なものであった。

本法は，CT装宣を用いるため，此較的简便に行うことができる。 